\title{
PENGABDIAN MASYARAKAT GERAKAN BAKTI SOSIAL PENYEMPROTAN DISINFEKTAN DAN BERBAGI PAKET SANTUNAN PEDULI COVID-19 DI PONDOK PASENTRAN BUKIT TENGKORAK NDAO KABUPATEN ENDE FLORES
}

\author{
Siti Arafat ${ }^{1)}$, Aschari Senjahari Rawe1), Nining Syariah"1), Adi Neneng Abdullah"1) \\ 1)Program Studi PGSD , FKIP, Universitas Flores, Ende, NTT, Indonesia \\ Corresponding author: Aschari Senjahari Rawe \\ E-mail : ascharisenjahrirawe@gmail.com
}

Diterima 19 Juni 2021, Direvisi 24 Juli 2021, Disetujui 25 Juli 2021

\begin{abstract}
ABSTRAK
Bakti sosial atau lebih dikenal dengan baksos ini merupakan suatu kegiatan wujud dari kepedulian atau rasa kemanusiaan terhadap sesama manusia. Dimana dengan adanya kegiatan ini kita dapat merekatkan rasa kekerabatan kita terhadap orang lain. Bakti dapat diartikan sebagai pengikatan (mengikatkan) diri kepada diri atau diri-diri lainnya. Ikatan Dosen Karyawan dan Mahasiswa Islam Universitas Flores (IDKMUF), ini berupa kepedulian, perasaan tanggungjawab terhadap kehidupan sesama. Bakti social dapat berarti memberi sesuatu (kepada yang butuh pemberian). Oleh karena itu,tujuan dari kegiataan ini Dosen Karyawan dan Mahasiswa Musim Universitas Flores,tergabung dalam ( IDKMUF). berusaha untuk membantu sesama yang kurang mampu dalam bentuk sumbangan santunan di pondok pasantren bukit tengkorak Ndao Ende Flores dan Penyemprotan Disinfektan dan Laundry Mukena di Masjid yang berada di wiayah Kota Ende. Hasil Kegiatan Gerakan Bakti Sosial Penyemprot dan Berbagi Paket Sembako Peduli Covid-19, Di mana bisa sedikit meringankan beban masyarakat yang terdampak langsung dari situasi pandemi Covid-9 ini. Inisiatif Dosen Karyawan dan Mahasiswa Muslim ini patut diapresiasi dan didukung penuh oleh pihak Yayasan dan Rektorat yang tergabung dalam tim pengabdian masyarakat ini dengan melakukan pendampingan sehingga kegiatan ini dapat terlaksana dengan baik.
\end{abstract}

Kata Kunci:, penyemprotan disinfektan; bakhti sosial; pembagian santunan.

\begin{abstract}
Social service or better known as social service is an activity that manifests concern or a sense of humanity towards fellow human beings. Where with this activity we can glue our sense of kinship to other people. Bakti can be interpreted as binding (binding) oneself to oneself or other selves. The Flores University Student and Employee Lecturer Association (IDKMUF) is a form of caring, a feeling of responsibility for the lives of others. Social service can mean giving something (to those who need it). Therefore, the purpose of this activity is the University of Flores Seasonal Employee and Student Lecturers, who are members of (IDKMUF). trying to help the less fortunate in the form of donations in the form of donations at the Ndao Ende Flores Islamic boarding school and the Spraying of Disinfectants and Mukena at the mosque in the Ende City area. The results of the Social Service Movement for Spraying and Sharing the Covid-19 Care Food Packages, which can slightly ease the burden on the people who are directly affected by the Covid-9 pandemic situation. This initiative of Muslim Employee Lecturers and Students should be appreciated and fully supported by the Foundation and the Rector who are members of this community service team by providing assistance so that this activity can be carried out properly.
\end{abstract}

Keywords: disinfectant spraying; social service; distribution of compensation.

\section{PENDAHULUAN}

Pada saat ini banyak permasalahan yang dihadapi masyarakat teutama karena dampak pandemik Covid-19. Kondisi ini tentu saja telah berimplikasi pada kehidupan dan pranata sosial baik di desa maupun pada masyarakat kota, Pandemik Covid-19 yang sedang melanda dunia termasuk Indonesia saat ini memaksa pemerintah menetapkan kebijakan bahwa masyarakat harus melakukan segala aktivitas dari rumah, baik itu bekerja, sampai aktivitas pendidikan dilakukan dari rumah.(Meilinda, 2020) Aktivitas ibadah keagaman persekolahan dan aktifitas lain tidak berjalan maksimal karena mendapat larangan dari pemerintah daerah masing-masing 
khususnya kota Ende. Oleh karena itu terjadinya permasalahan anak anak dipondok pasentren buktit tengkorak,terkendala oleh orang tuanya kurang mampu yang pekerjaanya sehari hari,nelayan,petani ladang,yang mengharapkan hasilnya di jual menyebabkan tekendala dengan pandemik Covid 19.hal tersebut anak anak sebagian besar yatim piatu dan orang tuanya penghasilanya pas - pasan, sehingga terkendala dalam makan minum mereka sehari hari dan di bebankan kepada yayasan buktit tengkorak,yang dikelolah, independen oleh ustat Alifudin,S.Ag,yang pendapatnya hanya seorang diri,tidak bisa membiayai anak anak yang jumlanya 246, dengan kondidisi seperti yang di alami secarang, pada masa pendemik covid 19.kendala yang kedua rumah ibadah yang setiap hari, selama sholad lima waktu dan sholad jumad yang banyak orang berkerumanan sehingga kami berinisiatif melakukan pencegahan dengan disinfektasi bekerjasama dengan badan tamir dan remaja masjid yang beradah di wilayah kota Ende.

Upaya pencegahan penyebaran covid19 diwilayah Kota Ende, Ikatan Dosen Karyawan dan Mahasiswa Universitas Flores, tengah melakukan penyemprotan Disinfektan., Dalam upaya pencegahan penyebaran covid19, Dosen,karyawan, mahasiswa Muslimin Universitas Flores terus melaksanakan upaya pencegahan dengan cara melakukan penyemprotan Disinfektan dilakukan di tempattempat umum seperti Mesjid, yang berada diwilayah kota Ende.(Setiawan, 2020) Pelaksanaan penyemprotan Disinfektan ini sudah yang kedua kalinya guna bertujuan agar dengan salah satu cara tersebut bisa memutus mata rantai penyebaran virus corona di daerah Kabupaten Ende, di Empat kecamatan yang berada diwilayah Kota Ende yaitu,Ende

\section{Selatan,Ende,Tengah,Ende}

Timur,Penyemprotan Disinfektan adalah salah satu pencegahan penyebaran virus, namun sebagai masyarakat kita juga bisa melakukan pencegahan dengan banyak cara seperti, tetap menjaga Kesehatan selalu menjaga Kebersihan, sering-sering cuci tangan dan masi banyak cara-cara yang sudah dihimbaukan Pemerintah.(Fitri et al., 2020)

Tim Pengabdaian Masyarakat Dosen dan Karyawan merupakan organisasi yang berada di bawah naungan Yayasan Perguruan Tinggi Universitas Flores. sebagai wadah untuk menyalurkan ide dan kontribusi, kepada masyarakat dalam bentuk bakti sosial pendidikan dan kemanusian yang nantinya dirasakan langsung oleh masyarakat. Baktii sosial dan pendidikan menjadi solusi alternatif atas problematika masyarakat sekarang. Baksos adalah suatu kegiatan yang nantinya akan menjadi wadah menjalin silaturahmi dan uhwa islam sesama umat beragama dan manfaat terhadap masyarakat. Dari bakhti social Penyemprotan Disinfektan dan pembagian Santun bagi anak anak pondok pasantren Bukit Tengkorak Ndao Ende Flores Nusa Tenggara Timur dalam proses kegiatan baksos ini, tim pengabdian masyarakat Dosen Karyawan akan mendampingi bersama mahasiswa muslim universitas flores untuk terjun langsung ke dalam masyarakat.(AlFaruqi et al., 2020)

Bakti sosial atau lebih dikenal dengan baksos ini merupakan suatu kegiatan wujud dari kepedulian atau rasa kemanusiaan terhadap sesama manusia. Dimana dengan adanya kegiatan ini kita dapat merekatkan rasa kekerabatan, silaturahim dan menigkat tali persaudaraan antara umat beragama kita terhadap orang lain. Kata sosial didalamnya tercakup perorangan dan kelompok-kelompok. Bakti dapat diartikan sebagai pengikatan mengikatkan diri kepada diri atau diri-diri lainnya. Ikatan Dosen Karyawan dan Mahasiswa Muslim. ini berupa kepedulian, perasaan tanggungjawab terhadap kehidupan sesama. (Tambunan et al., 2020)

Kegiatan baksos ini ditujukan untuk masyarakat yang membutuhkan perhatian dalam musibah bencana covid 19 di wilayah kota Ende yang mengalami kesulitan dalam memenuhi kebutuhan pokoknya karena situasi pandemi pada saat sekarang ini. Oleh karena itu, Dosen Karyawan dan Mahasiswa, berusaha untuk meringankan problem situasi bencana wabah covid 19 dalam bentuk Penyemprotan Disinfektan dan sumbangan paket santun sembako.(Diana, 2020).

\section{METODE}

\section{Tahap Perencanaan}

Tahap Pertama Perencanaan Sasaran pelaksanaan kegiatan ini adalah bermitra dengan Yayasan Pondok Pasentren Bukit tengkorak dapat memberikan dukungan dan kepedulian terhadap kegiatan positif yang dilaksanakan oleh mahasiswa dan Dosen Universitas Flores. Selain itu harapan tim pelaksana, dengan terlaksananya

kegiatan ini, masyarakat dapat terbantu walaupun tidak dalam jumlah besar namun gerakan ini bisa meringankan beban bagii anak pondok pasentren yang terbantu. Kegiatan ini berupa bakti sosial pembagian sembako dengan target jangkauan 150 orang

diskusi yang di tawarkan oleh penginisiati ibu Sabra B.wahab Thalib selaku Ketua Panitia Dosen Karyawan dan Mahasiswa 
Muslim Universitas Flores Dalam kegiaatan pengabdian masyarakat bakhti sosial Penyemprotan Disinfektan di 20 titik masjid yang beradah diwilayah kota Ende dan pembagian Santun bagi anak anak pondok pasantren Bukit Tengkorak Ndao Ende Flores Nusa Tenggara Timur ,tahap selanjutnya berdiskusi dan survey lokasi tempat mana sasaran yang membutuhkan penyemprotan Disinfektan dan pembagian Santunan Sembako, kemudian melakukan inisiatif Diskusi bersama untuk melakukan pengumpulan dana rejeki alakadar dari Dosen Karyawan Muslim Universitas Fores dan menyiapkan apa saja keperluan untuk Pengabdian Masyarakat yang dilakasanakan .(Rawe et al., 2021)

\section{Tahap Pelaksanaan}

Sasaran pelaksanaan kegiatan ini adalah Masjid yang berada di wilayah kota Ende yang bisa dijangkau dan diakses oleh Dosen dan mahasiswa Muslim Universitas Flores, kemudian bakhti social pembagian santunan sembako dapat memberikan dukungan dan kepedulian terhadap kegiatan positif yang dilaksanakan oleh Dosen dan mahasiswa Muslim Uniflor Ende terhadap Podok pasentren Bukit Tengkorak Ndao Kabupaten Ende Flores. Selain itu harapan tim pelaksana, dengan terlaksananya kegiatan ini, masyarakat dapat terbantu walaupun tidak dalam jumlah besar namun gerakan ini bisa meringankan beban bagi masyarakat yang terbantu. Kegiatan ini berupa bakti sosial pembagian sembako dengan target jangkauan anak anak Pondok Pasantren di seputaran Bukti Tengkorak Ndao.(Zahro et al., 2020)

\section{Tahap Evaluasi}

Evaluasi dilakukan setelah kegiatan dilaksanakan melalui laporan keuangan yang dilakukan secara transparan disajikan oleh panitia dan dipublikasi melalui media sosial akun Wabsapp Group Dosen dan Karyawan Universitas Flores sebagai bukti tanggung jawab panitia.(Yang et al., 2020)

\section{HASIL DAN PEMBAHASAN}

Metode Perencanaan Kegiataan Bakti Sosial Penyemprotan Disinfektan masjid di wilayah kota Ende dan sumbangan paket santun sembako di Pondok Pasantren Bukit Tengkorak, Perencaan awal inisiatif dari dosen dan mahasiswa muslim Universitas Flores. Mitra denganPandemi Covid-19 yang sedang melanda dunia termasuk Indonesia saat ini memaksa pemerintah menetapkan kebijakan bahwa masyarakat harus melakukan segala aktivitas dari rumah, baik itu bekerja, sampai aktivitas pendidikan dilakukan dari rumah. Di kota Ende khususnya, banyak kepala keluarga yang mengalami kesusahan akibat tidak bisa mencari nafkah karena dilarang melakukan aktivitas di luar rumah seperti tempat keramaian, fasilitas umum, maupun di tempat ibadah. Beberapa kasus tercatat bahkan ada beberapa keluarga yang kesulitan hanya untuk makan sehari-hari karena kehilangan mata pencaharian imbas dari Covid-19, bahkan ada juga yang nekat berjualan akan tetapi jualannya tidak laku. Program Pengabdian Masyarakat yang bersifat sosial ini Dosen dan Mahasiswa Universitas Flores, mengetuk hatinya untuk melakasanakan bakhti sosial. Jenis permasalahan yang ditangani dalam pengabdian masyarakat ini meliputi bakti sosial membantu masyarakat terdampak pandemi Covid-19 dalam memenuhi kebutuhan sembako (sembilan bahan pokok) di ruang lingkup Pondok Pasentren Bukit tengkorak. Kegiatan Gerakan Bakti Sosial Berbagi Paket Sembako Peduli Covid-19, merupakan salah satu kegiatan yang tepat dilakukan di masa pandemi Covid-19. Di mana bisa sedikit meringankan beban masyarakat yang terdampak langsung dari situasi pandemi Covid-9 ini. Inisiatif dari Dosen dan mahasiswa Muslim Universitas Flores ini patut diapresiasi dan didukung penuh oleh para dosen yang tergabung dalam tim pengabdian masyarakat ini dengan melakukan Penyemprotan Disinfektan sehingga kegiatan ini dapat terlaksana dengan baik.(Yusuf et al., 1998) Kegiatan ini dilaksanakan dalam 2 hari dengan agenda acara seperti yang ditunjukkan pada tabel 1.

Tabel 1. Agenda Acara Penyemprotan Disinfektan di Masjid diwilayah Kota Ende di Empat Kecamatan Kota dana Gerakan Bakti Sosial Berbagi Paket Sembako di Bukit Tengkorak Ndao.

\begin{tabular}{ccll}
\hline No & Hari/Tanggal & Acara & Waktu \\
\hline Sabtu, & Sesi I: Briefing dan doa bersama & 06.00 WIB - selesai \\
& seluruh tim yang terlibat dalam & \\
& kegiatan Bakti Sosial Penyemprotan & \\
& Disinfektan dan Laundry Mukena dan & \\
& pembersihan Lingkungan Masjid & \\
\hline
\end{tabular}




\begin{tabular}{|c|c|c|}
\hline & $\begin{array}{l}\text { Sesi II: Pembagian tim dan } \\
\text { lokasi kegiatan Bakti Sosial } \\
\text { Penyemprotan Disinfektan dan Laundry } \\
\text { Mukena dan pembersihan Lingkungan } \\
\text { Masjid } \\
\text { Sesi III: Tim turun langsung ke } \\
\text { lapangan untuk kegiatan Bakti Sosial } \\
\text { Penyemprotan Disinfektan dan Laundry } \\
\text { Mukena dan pembersihan Lingkungan } \\
\text { Masjid Sesi IV: Penutup: review dari } \\
\text { masing- } \\
\text { masing tim tentang kegiatan di lapangan }\end{array}$ & \\
\hline Sabtu, 01 April 2021 & $\begin{array}{l}\text { Sesi I: Briefing dan doa bersama } \\
\text { seluruh tim yang terlibat dalam } \\
\text { kegiatan Bakti Sosial penyerahan paket } \\
\text { sembako } \\
\text { Sesi II: seluruh tim ke lokasi } \\
\text { penyerahan paket sembako, sekaligus } \\
\text { pembukaan puasa bersama anak podok } \\
\text { pasentren bukit tekorak Ndao Ende } \\
\text { Flores NTT } \\
\text { Sesi III: Tim turun langsung ke } \\
\text { lapangan untuk membagikan paket } \\
\text { sembako dan Buka puasa bersama } \\
\text { Sesi IV: Penutup: review dari } \\
\text { masing- } \\
\text { masing seksi atau coordinator } \\
\text { Pembagian sembako dan buka puasa } \\
\text { bersama di pondok Pasantran Bukit } \\
\text { Tengkorak Ndao Ende Flores NTT. } \\
\text { tentang kegiatan di lapangan }\end{array}$ & $\begin{array}{l}16.00 \text { sampai } \\
\text { selesai }\end{array}$ \\
\hline
\end{tabular}

Secara keseluruhan kegiatan berjalan dengan baik sesuai dengan perencanaan. Semua pihak dapat bekerjasama dengan baik. Pihak dari Badan tamir masjid dan pimpinan Pondok Pasentren Bukit Tengkorak Ndao Ende Flores NTT begitu antusias dalam menerima paket sembako yang diberikan.(Linayati Lestari, Rona Tanjung, Karol Teovani Lodan, 2020).

Kegiatan pada Sesi I dapat dilihat pada Gambar 1. Di sesi pertama ini, lbu Sabra b, Wahab, S.E., M.Acc selaku ketua tim pengabdian pada masyarakat memimpin briefing singkat dan doa bersama. Termasuk memastikan kegiatan ini berjalan sesuai dengan protokol kesehatan pencegahan penyebaran Covid-19.

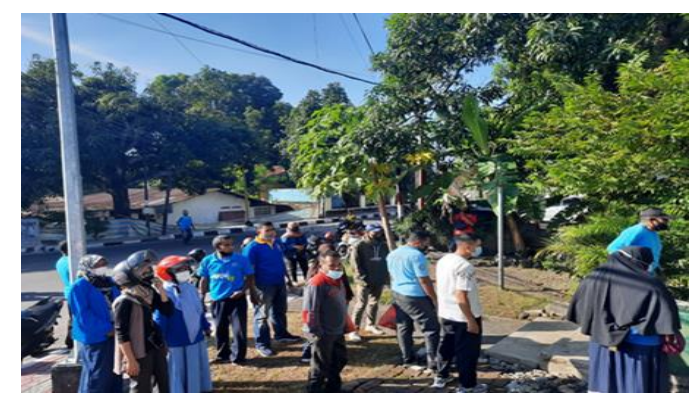

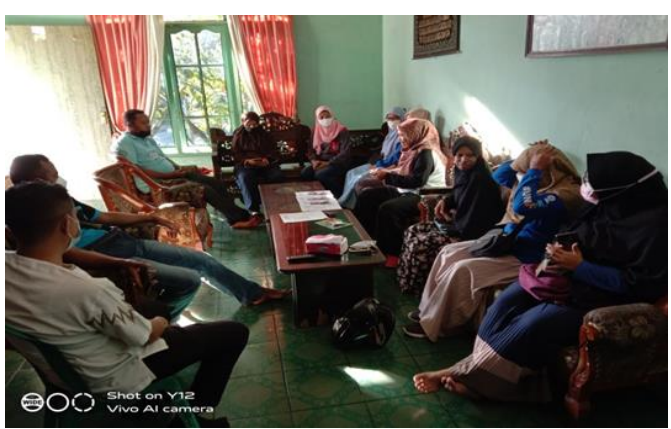

Gambar 1. Briefing dan doa bersama seluruh tim yang terlibat dalam kegiatan Bakti Sosial

Kegiatan pada Sesi II dapat dilihat pada Gambar 2. Di sesi ini, saudara Hamsa Doa,S.Pd.,M.Pd melakukan pendataan dan pembagian tim sesuai dengan lokasi yang telah direncanakan sebelumnya. 


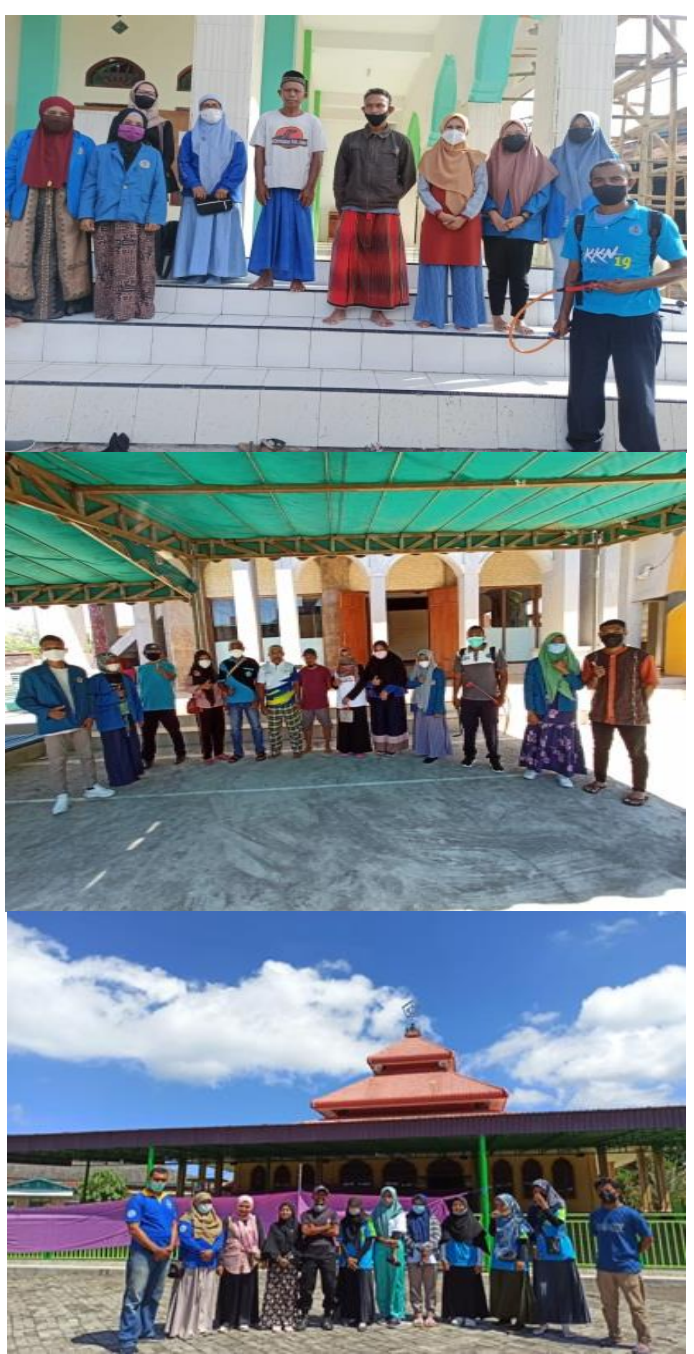

Gambar 2. Pembagian tim Penyemprotan Difektan dan lokasi penyerahan paket sembako

Kegiatan Sesi III dapat dilihat pada Gambar 3 dan Gambar 4. Pada sesi ini Tim turun langsung ke lapangan untuk penyemprotan difektan di masjid yang beradah di wilayah kota, yang terdiri empat kecamatan Ende Selatan, Ende Tengah,Ende Utara, Ende Timur dan membagikan paket sembako. Di Pondok pasantren Bukit Tengkorak Ndao Ende Flores Nusa Tenggara Timur.

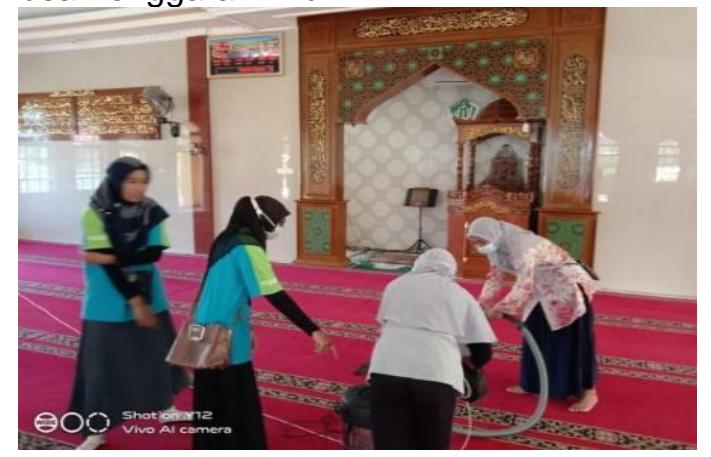

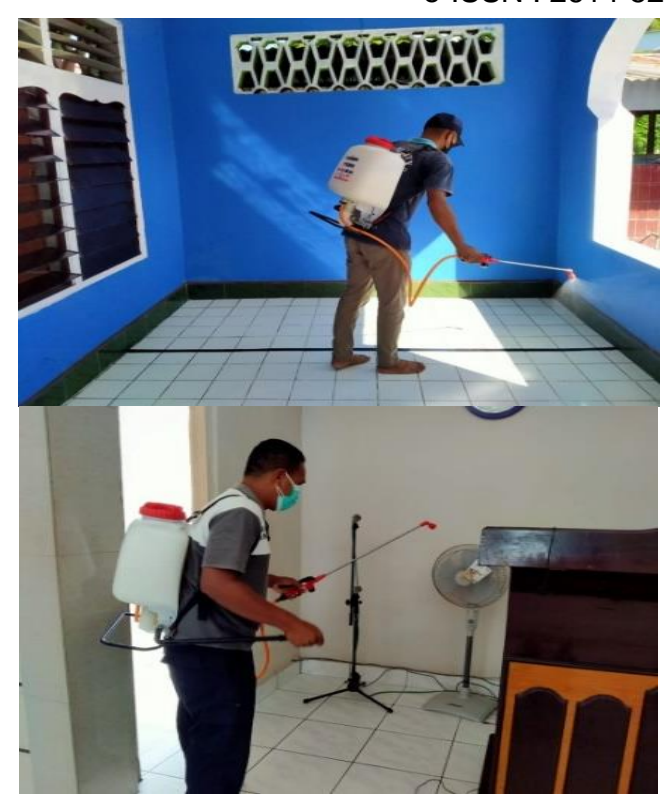

Gambar 3. Penyemprotan disinfektan

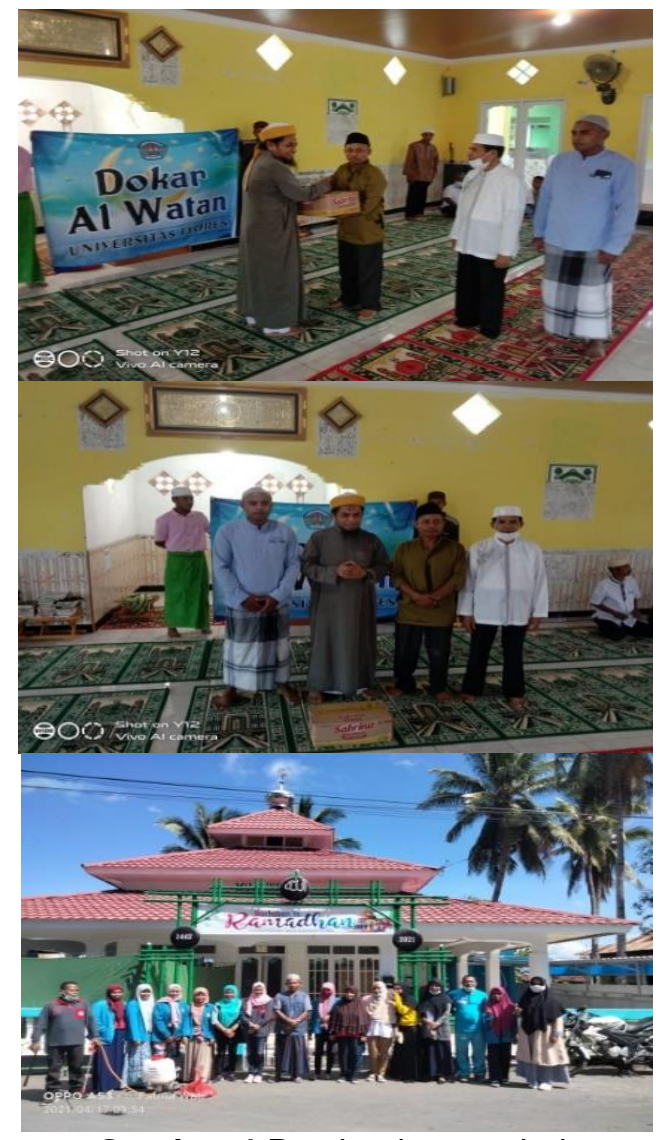

Gambar 4.Pembagian sembako 
Kegiatan Sesi IV dapat dilihat pada Gambar 5. Di sesi ini, lbu Sabra Wahab,SE.,M.Acc mengarahkan masingmasing tim untuk melakukan review kegiatan di lapangan, seperti kendala atau hal-hal yang terjadi di lapangan ketika melakukan pembagian paket sembako.

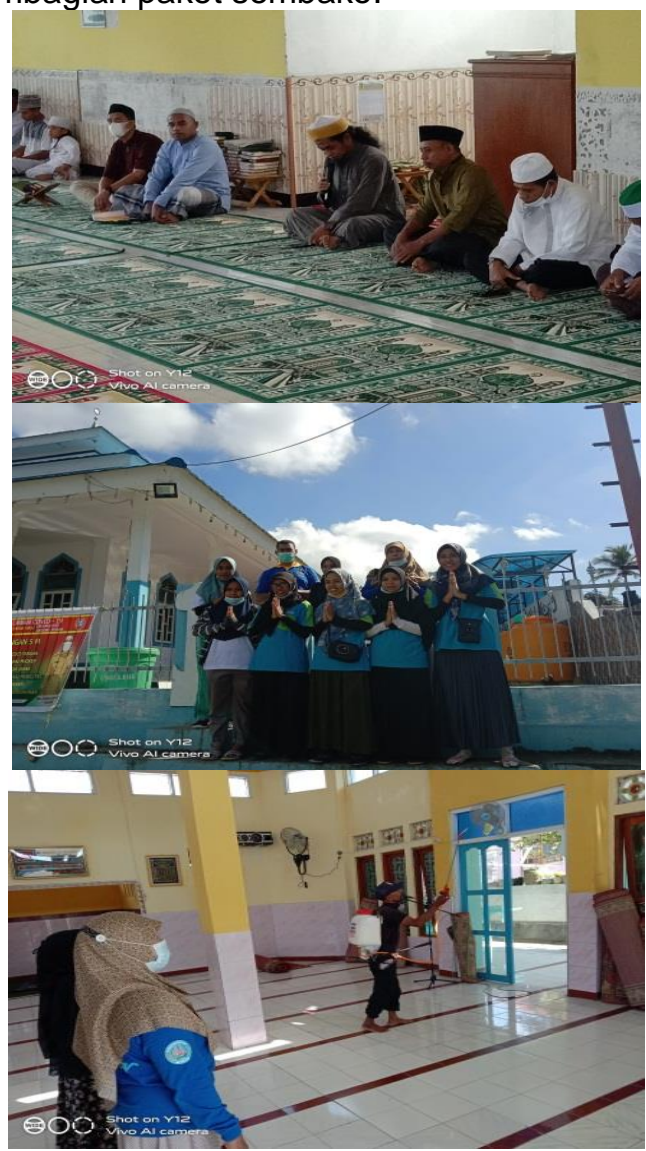

Gambar 5. Penutup: review dari masingmasing tim tentang kegiatan di lapangan, dan pertanggung jawaban Keuangan.

\section{SIMPULAN}

Kegiatan Gerakan Bakti Sosial Penyemprotan Disinfektan,Laundry Mukena dan Pembersihan di masjid di wilayah empat kecamatan kota Ende dan sumbangan paket santun sembako di Pondok Pasantren Bukit Tengkorak Ndao Ende Flores NTT,Berbagi Paket Sembako Peduli Covid-19, merupakan salah satu kegiatan yang tepat dilakukan di masa pandemi Covid-19. Di mana bisa sedikit meringankan beban masyarakat yang terdampak langsung dari situasi pandemi Covid-19 ini. Inisiatif Dosen karyawan dan Mahasiswa Muslim, ini patut diapresiasi dan didukung penuh oleh para dosen yang tergabung dalam tim pengabdian masyarakat ini dengan melakukan pendampingan sehingga kegiatan ini dapat terlaksana dengan baik.

\section{UCAPAN TERIMAKASIH}

Kami dari tim Pengabdian Kepada Masyarakat (PKM) mengucapkan terima kasih kepada Ketua Umum Yapertif,Rektor Universitas Flores, Ketua Badan Masjid diwilayah empat kecamatan di Kota Ende,khususnya Di Kecamatan Ende Tengah,yang meliputi kelurahaan Paupire masjid Al-Fuqram ,Onekore Masjid Papel ,Masjid Agung keluruhan Tetandara dan pimpinan pondok pasentren bukit tengkorak Ndao Ende Flores Nusa Tenggara Timur, yang telah mendukung kami dalam melaksanakan kegiatan PKM sebagai salah satu Tridarma di Perguruan Tinggi.

\section{DAFTAR RUJUKAN}

Al-Faruqi, R. A., Roshidayah, R., Najmah, H., \& Fajri, R. N. (2020). Kegiatan Bakti Sosial Untuk Membantu Ekonomi Lansia Di Desa Jambeyan Pada Era New Normal. SELAPARANG Jurnal Pengabdian Masyarakat Berkemajuan, 4(1), 617. https://doi.org/10.31764/jpmb.v4i1.336 9

Diana, M. (2020). Jurnal PKM Kebidanan Komunitas, Volume 4 Nomor 1 Tahun 2020 EDUKASI DAN PENCEGAHAN PENULARAN VIRUS COVID-19 PADA MASYARAKAT DESA PARIT BARU DAN PARIT ADONG KABUPATEN KUBU RAYA TAHUN 2020 COVID-19 adalah penyakit saluran pernafasan menular yang disebabkan. 4, 2-6.

Fitri, W., Octaria, M., \& Suwanny, N. (2020). Tantangan dan Solusi terhadap Ketimpangan Akses Pendidikan dan Layanan Kesehatan yang Memadai di Tengah Pandemi Covid-19. Jurnal Syntax ..., 1(10), 766-776. http://jurnal.syntaxtransformation.co.id/ index.php/jst/article/view/181

Linayati Lestari, Rona Tanjung, Karol Teovani Lodan, R. E. (2020). PENGABDIAN DONOR DARAH PADA MASYARAKAT "SETETES DARAH UNTUK KEMANUSIAAN DITENGAH PANDEMI COVID-19 “. Minda Baharu, 4(2), $\quad$ 62-67. https://www.journal.unrika.ac.id/index.p hp/MNDBHRU\%OADoi.

Meilinda, S. D. (2020). Covid-19: Struktur Masalah dan Pendekatan Kebijakan. Prosiding Seminar Nasional Problematika Sosial Pandemi Covid19, 82-88. https://www.ojs.literacyinstitute.org/ind ex.php/prosidingcovid19/article/view/43 
Rawe, A. S., Welu, F., Tola, D., \& Miten, A. O. (2021). Penyaluran bantuan bencana alam dan keterpenuhan kebutuhan korban bencana kebakaraan di rumah adat desa nggela kabupaten ende flores. SELAPARANG. Jurnal Pengabdian Masyarakat Berkemajuan, 4(April), 28-33.

Setiawan, A. (2020). Politik Luar Negeri Indonesia COVID-19: Penyelamatan dan Kerjasama. Independen, Jurnal Politk Indonesia Dan Global, 1(2), 6574.

https://doi.org/10.24853/independen.1. 2.65-74

Tambunan, E., Purba, M. L., \& ... (2020). Pendampingan Gerakan Bakti Sosial Berbagi Paket Sembako Peduli Covid19 Hima Manajemen Universitas Sari Mutiara Indonesia. Jurnal Abdimas Mutiara, 1(2), 58-63. http://ejournal.sari-

mutiara.ac.id/index.php/JAM/article/vie w/1311

Yang, M., Lingkungan, R., Dan, N., Sebagai, K., Ibadah, T., Pusat, D. A. N., Umat, K., \& Kelurahan, D. I. (2020). PEMBINAAN WARGA DAN DKM MASJID DALAM UPAYA MEWUJUDKAN SINDANG BARANG KECAMATAN BOGOR BARAT KOTA BOGOR Program Studi PAI STAI Al-Hidayah Bogor Program Studi Perbankan Syariah STAI AIHidayah Bogor Program Studi PAI STAI Al-Hidayah Bogor A . PENDAHULUAN Sek. JPMD: Jurnal Pengabdian Kepada Masyarakat Desa, 2(4), 101-113.

Yusuf, U. A., Syarifudin, M. A., \& Maulana, M. F. (1998). Pemakmuran Masjid Sebagai Sarana Ibadah dan Bantuan Sosial lainnya di Masyarakat Kelurahan Pasir Kuda Bogor Barat. 133-144.

Zahro, A., Abd, L. B., \& Abror, M. (2020). Program Bakti Sosial dan Metode Pembelajaran Al Qur ' an di Madrasah Hidayatul Mustaqim Desa Bulusari Kecamatan Tarokan Kabupaten Kediri. JPMD: Jurnal Pengabdian Kepada Masyarakat Desa, 1(1), 104-114. 